\title{
Antiviral Therapy for HCV-Associated Cryoglobulinemic Glomerulonephritis: Case Report and Review of the Literature
}

\author{
Fabrizio Fabrizi ${ }^{a} \quad$ Giovanni Battista Fogazzi $^{a}$ Donata Cresseri ${ }^{a}$ Patrizia Passerini ${ }^{a}$ \\ Paul Martin ${ }^{c}$ Maria Francesca Donato ${ }^{b}$ Maria Grazia Rumi ${ }^{b}$ Piergiorgio Messa ${ }^{a}$ \\ aDivision of Nephrology, Maggiore Hospital, IRCCS Foundation, and b Division of Gastroenterology, \\ Maggiore Hospital and University School of Medicine, Milan, Italy; ${ }^{\mathrm{C}}$ Division of Hepatology, School of Medicine, \\ University of Miami, Miami, Fla., USA
}

\section{Key Words}

Hepatitis C • Glomerulonephritis - Cryoglobulinemia •

Interferon · Rituximab

\begin{abstract}
We describe the case of a 51-year-old woman with HCVassociated cryoglobulinemic glomerulonephritis (GN). She presented mild deterioration of kidney function, non-nephrotic proteinuria, and active urinary sediment. Kidney biopsy showed features of membranoproliferative changes with some sclerosis. Sustained viral response (SVR) was obtained by 6 months of antiviral therapy (peg-IFN- $\alpha 2$ a plus ribavirin). SVR was linked with improvement of kidney function and remission of proteinuria. Clinical and virological remission persists over a 25-month follow-up. This case report emphasizes efficacy and safety of antiviral treatment of HCVassociated glomerulonephritis - preliminary but encouraging results exist. We identified by systematic review of the literature 9 studies (156 unique patients); the pooled estimate of frequency of sustained virological response after IFN-based therapy was 0.49 (95\% confidence interval, Cl: $0.21,0.77 ; p<0.0005$; random effects model). Heterogeneity was found $\left(I^{2}=98.9 \%, p<0.0001\right)$. Two possible regimens should be considered for the treatment of HCV-associated
\end{abstract}

cryoglobulinemic GN according to the clinical presentation. Immunosuppressive therapy is recommended for HCV-related kidney disease having aggressive course, and recent evidence supports rituximab (RTX) use with a reduced exposure to corticosteroids. We identified six studies (66 unique patients) on RTX therapy for HCV-associated kidney disease; at the end of RTX therapy, the pooled estimate of the mean decrease in proteinuria was $1.4 \mathrm{~g} / 24 \mathrm{~h}(95 \% \mathrm{Cl}: 0.75,2.05, \mathrm{p}<$ 0.001 ); The $p$ test for heterogeneity gave a value of 0.94 $\left(I^{2}=0\right)$. Several questions related to RTX use remain. HCVinduced GN is uncommon among CKD patients of developed countries, and this clearly hampers prospective controlled clinical trials aimed to evaluate efficacy and safety of antiviral or immunosuppressive therapy in this population.

Copyright $\odot 2013$ S. Karger AG, Basel

\section{Introduction}

Patients with long-standing HCV infection can develop chronic hepatitis, liver cirrhosis, and hepatocellular carcinoma. Several extrahepatic complications have also been associated with HCV including hematologic and dermatologic diseases as well as autoimmune and kidney diseases [1]. A strong relationship between HCV infec-

\section{KARGER \\ Fax +4161306 1234 \\ E-Mail karger@karger.ch}

www.karger.com
(C) 2013 S. Karger AG, Basel

1420-4096/12/0356-0687\$38.00/0

Accessible online at:

www.karger.com/kbr
Fabrizio Fabrizi, MD

Division of Nephrology, Maggiore Hospital, IRCCS Foundation, Pad. Croff Via Commenda 15

IT-20122 Milan (Italy)

E-Mail fabrizi@policlinico.mi.it 
tion and cryoglobulinemia has been found since early 1990s [2, 3]. More recent evidence has been accumulated showing a link between HCV infection and immune complex glomerular diseases, including membranoproliferative glomerulonephritis (MPGN) and membranous nephropathy [4-7]. Less frequently described lesions are MPGN without cryoglobulinemia, focal segmental glomerulosclerosis, IgA nephropathy or fibrillary and immunotactoid glomerulopathies [4-7]. Hepatitis C virusassociated tubulointerstitial injury has also been reported [8].

The discovery of HCV and a better understanding of pathophysiological mechanisms provided the opportunity to control $\mathrm{HCV}$-associated MPGN using various approaches: (1) antiviral therapy based on the belief that the underlying infection is driving immune complex formation and resultant vasculitis; (2) non-specific immunosuppressive therapy targeting inflammatory cells present in vasculitic lesions, and (3) B cell depletion therapy targeting $\mathrm{B}$ cells which produce cryoglobulins. It is clear that prospective randomized, controlled clinical trials (RCTs) are mandatory to make evidence-based recommendations to treat $\mathrm{HCV}$-associated glomerulonephritis (GN) [9]. Until this information is available, two possible regimens have been recommended for the treatment of cryoglobulinemic or non-cryoglobulinemic $\mathrm{HCV}$-associated GN, depending on the severity of proteinuria and kidney failure (table 1). In patients with moderate proteinuria and slow loss of kidney function, antiviral therapy targeted at achieving clearance of HCV RNA with sustained viral response (SVR) has been successfully used. The use of steroid pulses with cytotoxic agents and plasma exchange has been suggested for patients with nephrotic proteinuria, and/or rapidly progressive loss of kidney function and an acute flare of cryoglobulinemia; after control of the vasculitic syndrome has been achieved, antiviral therapy should be started [9].

We report herein a case of HCV-related MPGN that was successfully treated with antiviral therapy. A systematic review of the literature on the efficacy and safety of therapy for $\mathrm{HCV}$-associated $\mathrm{GN}$ was also performed.

\section{Case Report}

A 51-year-old Caucasian female was diagnosed with chronic hepatitis C (genotype 2) in May 1998. She showed palpable purpura that was first treated with methotrexate, chloroquine, and then low-dose oral corticosteroids. In June 1998, electromyography revealed axonal neuropathy with sensitive abnormalities of the legs. In January 2009, she was admitted to the Division of Di-
Table 1. Treatment of HCV-related glomerular disease according to the clinical presentation

Patients with mild proteinuria and slow progressive kidney failure

- Anti-HCV therapy for 12 months

- Pegylated IFN $\alpha 2 \mathrm{a}: 180 \mu \mathrm{g} /$ week SQ (135 $\mu \mathrm{g} /$ week in patients with reduced glomerular filtration rate)

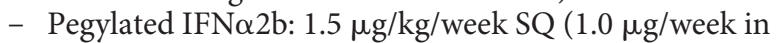
patients with low GFR)

- Ribavirin 800-1,200 mg day orally (for patients with GFR $<50 \mathrm{ml} / \mathrm{min}$ : low ribavirin dose, 200-600 mg/day, and erythropoietin supplementation)

- Symptomatic therapy: ACE inhibitors and/or angiotensin receptor blockers to reduce proteinuria, diuretics

Patients with nephrotic proteinuria and/or progressive kidney

failure

- Methylprednisolone pulses: 0.5-1.0 g/day for three consecutive days, then oral corticosteroids

- Cyclophosphamide: $1.5-2.0 \mathrm{mg} / \mathrm{kg} / \mathrm{day}$ (2-4 months; oral route)

- RTX: $375 \mathrm{mg} / \mathrm{m}^{2} /$ week for 4 weeks (intravenous route)

- Plasma exchange: 31 of plasma thrice weekly for 2-3 weeks

- Anti-HCV therapy for 12 months (as shown above)

- Symptomatic therapy (as shown above)

gestive Diseases, Maggiore Hospital, for multifactorial anemia (at that time, serum creatinine $1.36 \mathrm{mg} / \mathrm{dl}$ ). Several erosions at the duodenum with active bleeding were detected by endoscopy. Beginning in September 2009, the patient had a progressive decline of the kidney function (serum creatinine rose from 1.36 to a maximum of $1.67 \mathrm{mg} / \mathrm{dl}$ ) with non-nephrotic proteinuria $(2 \mathrm{~g} / 24 \mathrm{~h})$. Arterial hypertension occurred, and therapy with angiotensinconverting enzyme inhibitors and angiotensin receptor blockers was instituted with a small benefit on proteinuria. The patient was admitted (October 2009) to the Nephrology Division, Maggiore Hospital, and renal biopsy was performed. On physical examination, palpable purpura extended to the trunk with bilateral edema of the lower extremities. Serum creatinine was $1.3 \mathrm{mg} / \mathrm{dl}$, antiHCV positive, HCV RNA positive (13,762 copies/ml), cryocrit was $1 \%$, rheumatoid factor $276 \mathrm{IU} / \mathrm{l}(0-14 \mathrm{IU} / \mathrm{l})$, and C4 concentration $10 \mathrm{mg} / \mathrm{dl}$ (17-33 mg/dl). She had a monoclonal IgMk cryoglobulin with a polyclonal IgG component. Normal serum immunoglobulins (IgG, IgA, IgM), complement $\mathrm{C}_{3}$ and electrophoresis were found. Several serologic markers were in the normal range including anti-nuclear antibody, anti-double-stranded DNA (antiDNA), and anti-neutrophil cytoplasmic antibodies. Other findings included GOT $16 \mathrm{IU} / \mathrm{l}, \mathrm{GPT} 9 \mathrm{IU} / \mathrm{l}, \gamma$-glutamyltranspeptidase $8 \mathrm{IU} / \mathrm{l}$, and total bilirubin $0.15 \mathrm{mg} / \mathrm{dl}$. Proteinuria was $1.13 \mathrm{~g} / 24 \mathrm{~h}$, and urine sediment, analyzed by phase-contrast microscopy, showed severe microscopic hematuria (90-100 erythrocytes/ microscopic field, 56\% having dysmorphic nature, $12 \%$ acanthocytes), and numerous granular, and red cell casts. Kidney histology showed 21 glomeruli, 16 of which were diffusely and uniformly abnormal with features characteristic of membranoproliferative nephritis (double contour appearance of the capillary wall, centrolobular sclerosis, mesangial cell proliferation, endoluminal mononuclear cells, and mesangial matrix expansion). 


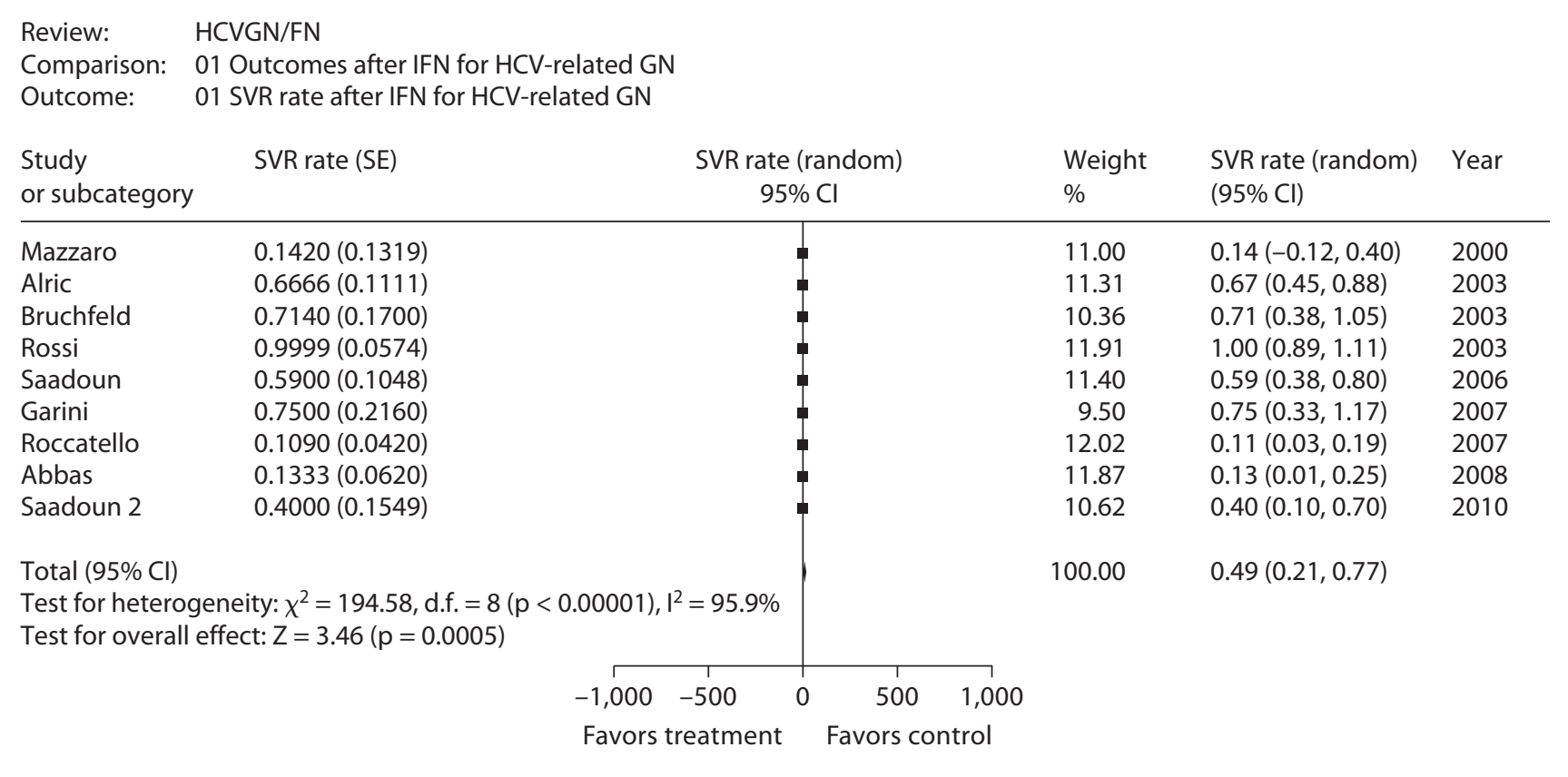

Fig. 1. HCV-related GN: viral response after IFN.

Global sclerosis was observed in five glomeruli. Interstitial fibrosis and moderate atherosclerosis were also present. Immunofluorescence exhibited isolated IgM deposition in sclerotic areas. Antiviral therapy was started (subcutaneous administration of pegIFN- $\alpha 2 \mathrm{a} 180 \mu \mathrm{g}$ weekly and oral ribavirin $400 \mathrm{mg}$ twice a day), and prednisone therapy (5 $\mathrm{mg}$ on alternate days) was continued. Subcutaneous darbepoetin ( $40 \mu \mathrm{g}$ weekly) was also given.

Complete resolution of the cutaneous manifestations and edema was noted after a few weeks of antiviral therapy. The patient required transfusion with 3 units of packed red blood cells (January 2010) due to severe anemia (Hb $6.8 \mathrm{~g} / \mathrm{dl}$ ); thus, therapy was modified as follows: peg-IFN- $\alpha 135 \mu$ g s.c. weekly, ribavirin $200 \mathrm{mg}$ twice a day, no prednisone, and darbepoetin dose progressively was increased to $100 \mu \mathrm{g}$ weekly. HCV RNA clearance occurred in January 2010. Antiviral therapy was discontinued in April 2010; at that time, the patient had normal protein excretion $(0.09 \mathrm{~g} / 24 \mathrm{~h})$ with very mild microscopic hematuria. A slow improvement of kidney function was found with serum creatinine $1.16 \mathrm{mg} / \mathrm{dl}$. HCV RNA and serum cryoglobulin tests were repeatedly negative. Twenty-five months after completing antiviral therapy (May 2012), continued follow-up showed stable clinical conditions - proteinuria of $0.15 \mathrm{~g} / 24 \mathrm{~h}$, serum creatinine $1.13 \mathrm{mg} / \mathrm{dl}$ (glomerular filtration rate according to MDRD equation of $63 \mathrm{ml} / \mathrm{min}$ ) and mild microscopic hematuria (2-4 erythrocytes/microscopic field, 54\% of them dysmorphic; no acanthocytes, no casts). Normal serum complement $\left(\mathrm{C}_{3} / \mathrm{C}_{4}\right)$ was noted. Her medications currently include nifedipine, ranitidine, and doxazosin.

Antiviral Therapy for HCV-Associated Glomerulonephritis

\section{Review of the Literature}

A systematic review of the medical literature was done by PubMed search up to August 31, 2012; the key words 'cryoglobulinemia', 'glomerulonephritis', 'HCV infection', 'interferon', 'rituximab' were used to identify clinical studies on antiviral (or rituximab, RTX) treatment of $\mathrm{HCV}$-associated kidney disease. Review papers and case reports were excluded. Some manuscripts were excluded as they gave information on patients already reported in prior publications $[10,11]$, others gave incomplete results [12-18].

We identified 9 clinical studies on antiviral therapy for HCV-associated GN ( $\mathrm{n}=156$ unique patients; fig. 1) [1927]; the rate of SVR ranged between 14 and $100 \%$. As listed in figure 1 , the summary estimate of frequency of SVR was 0.49 (95\% confidence interval, CI: 0.21, 0.77; randomeffects model). Significant heterogeneity was noted.

A total of six studies on RTX for HCV-associated glomerular disease was considered in this review [28-33]; only these satisfied our inclusion criteria, i.e. detailed information on HCV-associated kidney disease at baseline and over follow-up. Various reports on RTX therapy for symptomatic $\mathrm{HCV}$-associated mixed cryoglobulinemia 


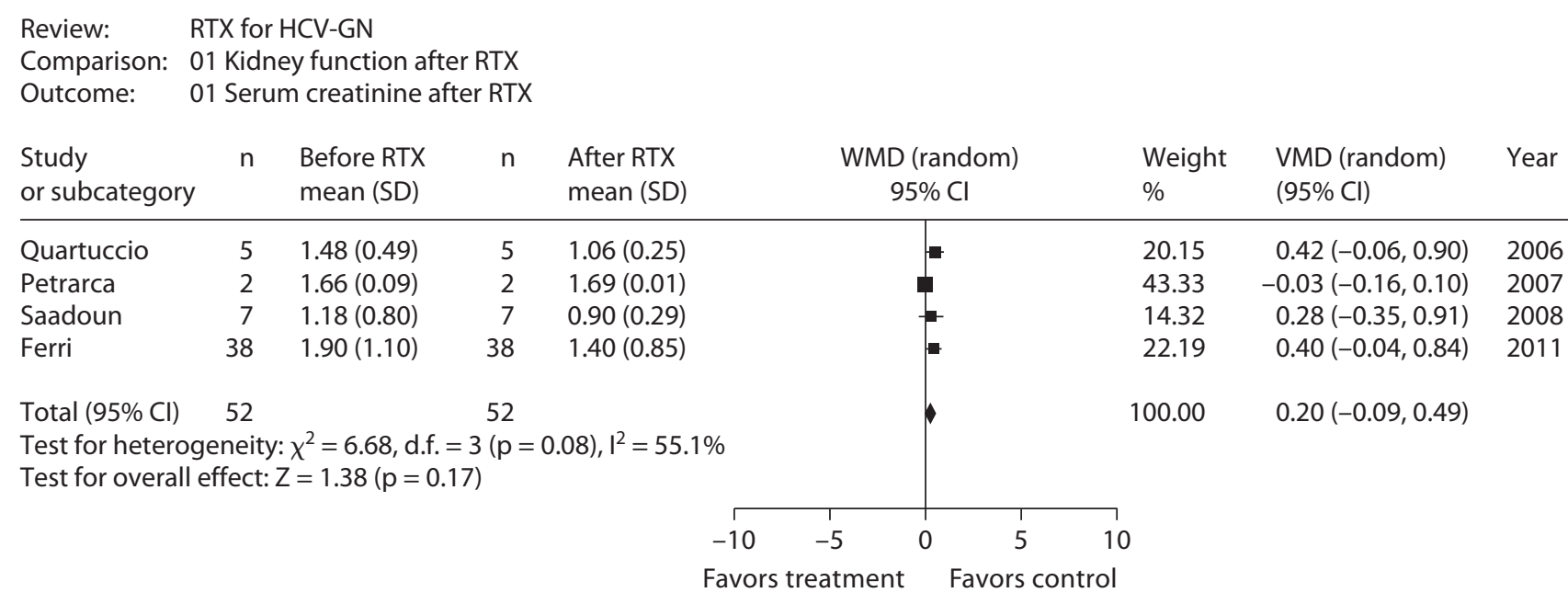

Fig. 2. HCV-related GN: serum creatinine after RTX.

(HCV-MC) with kidney involvement have been published; some of them mentioning the 'partial' or 'complete' remission of kidney disease after RTX, but no clear information on daily proteinuria or serum creatinine was given [34-35]. The number of patients with kidney disease was small (66 unique patients; table 2); renal involvement ranged from proteinuria, nephrotic or nephritic syndrome, to chronic kidney disease. All patients had symptomatic $\mathrm{HCV}-\mathrm{MC}$, the majority being non-cirrhotic with HCV genotype 1 . As shown in table 3, RTX appears effective for HCV-related kidney disease; the pooled mean difference of decrease in serum creatinine after RTX was $0.20 \mathrm{mg} / \mathrm{dl}$ (95\% CI: $-0.09,0.49 ; \mathrm{p}=0.55)$, no heterogeneity was noted ( $\mathrm{p}=0.08 ; \mathrm{I}^{2}=55.1 \%$; fig. 2$)$. Information on daily proteinuria was given in three reports only; the pooled mean difference of proteinuria decrease after RTX was $1.40 \mathrm{~g} / 24 \mathrm{~h}$ (95\% CI: 0.75, 2.05; p < 0.0001); $\mathrm{p}$ test for heterogeneity was not significant.

\section{Discussion}

HCV has been associated with glomerular lesions in native and transplanted kidneys. The exact prevalence of these renal manifestations is probably low, and the available evidence on this issue is limited; to date, the most important survey has been done on male veterans hospitalized in the USA in the 1990s [36]; membranoproliferative GN was more frequent among HCV positive- than
HCV-negative individuals (0.36 vs. $0.05 \%, \mathrm{p}<0.0001$ ). No difference occurred on membranous nephropathy (0.33 vs. $0.19 \%, p=0.86$ ).

Our case emphasizes the efficacy of antiviral therapy for HCV-associated GN; the mild kidney disease and the absence of aggressive involvement of other organs suggested an antiviral approach. We observed a close relationship between persistent clearance of HCV viremia and remission of urinary abnormalities. Tolerance to antiviral therapy was not excellent as the patient needed blood transfusions; however, this side effect disappeared after dose reduction of antiviral drugs. She received a 6-month course of antiviral therapy even if the KDIGO guidelines recommend antiviral therapy for at least 12 months irrespective of HCV genotype [9].

Our systematic review demonstrated the limited number of studies addressing the antiviral therapy of HCVrelated GN, only small observational studies exist [37]. In addition, the impact of antiviral therapy on long-term outcomes of kidney disease remains unclear. As reported in figure 1, initial studies (based on IFN alone) not surprisingly gave high relapse rates, but with the gold standard of HCV treatment (pegylated IFN plus ribavirin), the viral response was better. Of note, in all patients with proteinuria reduction, HCV RNA clearance was documented at the end of IFN therapy.

With multiorgan involvement, the antiviral therapy may be limited due to treatment failure, adverse effects, contraindications, or severe renal disease. On the other 
Table 2. Rituximab therapy of HCV-associated cryoglobulinemic GN: baseline characteristics and RTX schedule

\begin{tabular}{|c|c|c|c|c|c|c|}
\hline & \multicolumn{6}{|l|}{ First author } \\
\hline Year & 2006 & 2007 & 2008 & 2008 & 2011 & 2012 \\
\hline Country & Italy & Italy & Italy & France & Italy & Italy \\
\hline Patients & 5 & 2 & 12 & 16 & 87 & 28 \\
\hline Age, years & $57.2(45-65)$ & 61.5 & $61.9(37-76)$ & $58 \pm 10.5$ & $61.3 \pm 11.4$ & $62.8 \pm 11.4$ \\
\hline Male & $1(20 \%)$ & $1(50 \%)$ & NA & $3(19 \%)$ & $19(22 \%)$ & $4(14 \%)$ \\
\hline Rheumatoid factor, IU/ml & $1.783(146-3,910)$ & 14,207 & $512(272-750)$ & $173.3 \pm 55.7$ & NA & $501.4 \pm 891$ \\
\hline $\mathrm{C} 4, \mathrm{mg} / \mathrm{dl}$ & $6.2(2-12)$ & $6.5(1-12)$ & $5.2(4-8)$ & $6.2 \pm 9$ & NA & $6.27 \pm 8.7$ \\
\hline $\mathrm{IgM}, \mathrm{mg} / \mathrm{dl}$ & 387.2 & NA & $480(250-650)$ & $180 \pm 700$ & NA & NA \\
\hline Kidney disease & $5(100 \%)$ & $2(100 \%)$ & $7(58 \%)$ & $7(43.8 \%)$ & $38(43.6 \%)$ & $7(25 \%)$ \\
\hline Purpura & $80 \%$ & $100 \%$ & NA & $81 \%$ & $59 \%$ & NA \\
\hline Skin ulcers & 0 & 0 & $3(25 \%)$ & $2(12.5 \%)$ & $24(27 \%)$ & $5(17.8 \%)$ \\
\hline
\end{tabular}

NA $=$ Not available.

Table 3. RTX therapy of HCV-associated cryoglobulinemic GN: follow-up results on proteinuria $(\mathrm{g} / 24 \mathrm{~h})$ and serum creatinine $(\mathrm{mg} / \mathrm{dl})$

\begin{tabular}{lll}
\hline First author & $\begin{array}{l}\text { Daily proteinuria } \\
\text { baseline/follow-up }\end{array}$ & $\begin{array}{l}\text { Serum creatinine } \\
\text { baseline/follow-up }\end{array}$ \\
\hline Ferri & $2.2 \pm 2.1 / 0.9 \pm 1.75$ & $1.8 \pm 1.1 / 1.4 \pm 0.85$ \\
Roccatello & $1.6 / 0.3$ & $\mathrm{NA}$ \\
Quartuccio & $1.74 \pm 1.3 / 0.2 \pm 0.2$ & $1.48 \pm 0.49 / 1.06 \pm 0.25$ \\
De Vita & $2(0.6-7.9) / 0.9(0.5-4.5)$ & $1.6(0.7-2.8) / 1.6(0.8-0)$ \\
Petrarca & $\mathrm{NA}$ & $1.66 \pm 0.09 / 1.69 \pm 0.01$ \\
Saadoun & $1.6 \pm 2.5 / 0.1 \pm 0.2$ & $1.18 \pm 0.8 / 0.9 \pm 0.29$ \\
\hline
\end{tabular}

NA $=$ Not available.

hand, conventional immunosuppressive therapy may be poorly tolerated or ineffective. Therefore, new treatment options such as RTX, a human-mouse chimeric monoclonal antibody, have been proposed. RTX binds to the B cell surface antigen CD20 and depletes the expanded B cell clone or clones producing rheumatoid factor and cryoglobulins. Several groups have first reported on the efficacy of RTX in patients with symptomatic HCV-MC vasculitis resistant or intolerant to IFN- $\alpha$ monotherapy. A complete clinical response was reported in $60-70 \%$ of cases, with cryoglobulin clearance in one third of patients
$[34,35]$. Recently, two RCTs showed that RTX was superior to conventional immunosuppressive agents (i.e. corticosteroids, plasma exchange, and azathioprine or cyclophosphamide) for treating symptomatic HCV-MC [33, 38]. No change in HCV viral load was noted following RTX therapy, according to one RCT [38]; in another RCT, the frequency of adverse side effects was higher in the RTX than the control group, even if the difference did not reach statistical significance ( 21.5 vs. $10 \%$ ) [33]. Thus, a word of caution is important as the use of RTX has been associated with the activation of various infections, particularly after solid organ transplantation $[39,40]$.

The absence of efficacy on HCV clearance is a matter of concern, and the high relapse rates observed in some reports support the need for antiviral therapy to block the infection trigger and obviate long-term liver complications. A recent prospective controlled trial showed the superiority of a combination of RTX plus Peg-IFN- $\alpha 2 b-$ ribavirin compared to Peg-IFN- $\alpha 2 b$-ribavirin alone in symptomatic HCV-MC. A complete clinical response was noted in $80.9 \%(17 / 21)$ of patients with kidney involvement in the RTX plus Peg-IFN- $\alpha 2 b$-ribavirin group, the CR being 40\% (4/10) among patients with kidney disease on Peg-IFN- $\alpha 2 b$-ribavirin alone $(p<0.04)$ [27]. Thus, the association of RTX with combined antiviral therapy may be an appropriate choice for symptomatic HCV-MC, but its safety and efficacy needs to be better addressed. 
Two direct-acting antiviral agents, boceprevir and telaprevir, have been recently licensed; they lower the activity of the HCV non-structural protein 3-4A serine protease and increase the viral response in genotype 1 $\mathrm{HCV}$ infection when used in combination with Peg-IFN and ribavirin [41-42]. Novel guidelines now recommend the triple antiviral therapy for treatment of genotype $1 \mathrm{HCV}$ infection [43]. No studies evaluating efficacy and safety of triple therapy for patients with symptomatic HCV-MC exist, and evidence on direct-acting anti-HCV agents is currently limited to patients with intact kidney function.

Another alternative treatment for $\mathrm{HCV}$-associated MC vasculitis is low-dose interleukin-2 (IL-2), a cytokine that promotes survival and function of regulatory $\mathrm{T}$ cells (Tregs). Patients with vasculitis induced by HCV have reduced levels of Tregs. Resolution of HCV infection correlates with cure of vasculitis and the recovery of Treg levels. Preliminary data suggest that IL-2 supports an attenuation of inflammatory signs in patients with HCV- induced vasculitis that was refractory to antiviral therapy, RTX or both [44]. No serious adverse events were noted. Additional studies are essential before wider implementation of this treatment strategy.

In conclusion, our case report emphasizes the efficacy and safety of combined anti-HCV therapy for HCV-positive GN. Viral response was associated with remission of urinary abnormalities and improvement of kidney function. A major concern is the lack of long-term studies on patient/kidney outcomes after treatment of HCV-associated nephropathy. Prospective studies are needed to detail the role of RTX in cryoglobulinemic HCV-positive GN; also, the most effective therapy for relapses of cryoglobulinemia or HCV replication after a successful initial course of treatment remains unclear.

\section{Acknowledgements}

This work was supported in part by the grant 'Project Glomerulonephritis' in memory of Pippo Neglia.

\section{References}

1 Lauer G, Walker B: Hepatitis C virus infection. N Engl J Med 2001;345:41-52.

-2 Pascual M, Perrin L, Giostra E, Schifer J: Hepatitis $C$ virus in patients with cryoglobulinemia type II. J Infect Dis 1990;162:567569.

> Ferri C, Greco F, Longombardo G, Palla P, Moretti A, Marzo E, Foselle P, Pasero G, Bombardieri S: Antibodies to hepatitis C virus in patients with mixed cryoglobulinemia. Arthritis Rheum 1991;34:1606-1610.

-4 Agnello V, Chung R, Kaplan L: A role of hepatitis $\mathrm{C}$ infection in type II cryoglobulinemia. N Engl J Med 1992;327:1490-1495.

5 Fabrizi F, Colucci P, Ponticelli C, Locatelli F: Kidney and liver involvement in cryoglobulinemia. Semin Nephrol 2002;22:309-318.

-6 Johnson R, Willson R, Yamabe H, Couser W, Alpers C, Wener M, Davis C, Gretch D: Renal manifestations of hepatitis $C$ virus infection. Kidney Int 1994;46:1255-1263.

7 D'Amico G: Renal involvement in hepatitis C infection: cryoglobulinemic glomerulonephritis. Kidney Int 1998;54:650-671.

-8 Kasuno K, Ono T, Matsumori A, Nogaki F, Kusano H, Watanabe H, Yodoi J, Muso E: Hepatitis C virus associated tubulo-interstitial injury. Am J Kidney Dis 2003;41:767775.

-9 Kidney Disease: Improving Global Outcomes. KDIGO clinical practice guidelines for the prevention, diagnosis, evaluation, and treatment of hepatitis $\mathrm{C}$ in chronic kidney disease. Kidney Int 2008;73(suppl 109):S1-S99.
10 Roccatello D, Baldovino S, Rossi D, Mansouri M, Naretto C, Gennaro M, Cavallo R, Alper M, Costanzo P, Giachino O, Mazzucco G, Sena L: Long-term effects of anti-CD20 monoclonal antibody treatment of cryoglobulinaemic glomerulonephritis. Nephrol Dial Transplant 2004;19:3054-3061.

11 Garini G, Allegri L, Carnevali L, et al: Interferon alfa in combination with ribavirin as initial treatment for hepatitis $C$ virus-associated cryoglobulinemic membranoproliferative glomerulonephritis. Am J Kidney Dis 2001;38:E35-E39.

12 Johnson R, Gretch D, Couser W, Alpers C, Willson J, Chung M, Hart J, Willson R: Hepatitis $C$ virus-associated glomerulonephritis. Effect of alpha-interferon therapy. Kidney Int 1994;46:1700-1704.

13 Stehman-Breen C, Alpers C, Couser W, Willson R, Johnson R: Hepatitis C virus associated membranous glomerulonephritis. Clin Nephrol 1995;44:141-147.

14 Fabrizi F, Pozzi C, Farina M, Dattolo P, Lunghi G, Badalamenti S, Pagano A, Locatelli $F$ : Hepatitis $C$ virus infection and acute or chronic glomerulonephritis: an epidemiological and clinical appraisal. Nephrol Dial Transplant 1998;13:1991-1997.

15 Komatsuda A, Imai H, Wakui H, Hamai K, Ohtani H, Kodama T, Oyama Y, Nakamoto Y: Clinicopathological analysis and therapy in hepatitis $\mathrm{C}$ virus-associated nephropathy. Intern Med 1996;35:529-533.
16 Al-Wakeel J, Mitwalli A, Tarif N, Al-Mohaya S, Malik G, Khalil M: Role of interferon-alpha in the treatment of primary glomerulonephritis. Am J Kidney Dis 1999;33:11421146.

17 Beddhu S, Bastacky S, Johnson J: The clinical and morphologic spectrum of renal cryoglobulinemia. Medicine (Baltimore) 2002; 81:398-409.

18 Colucci G, Manno C, Grandaliano G, Schena FP: Cryoglobulinemic membrano-proliferative glomerulonephritis: beyond conventional therapy. Clin Nephrol 2011;75:374379.

19 Mazzaro C, Panarello G, Carniello S, Faelli A, Mazzi G, Crovatto M, Baracetti S, Nascimbeni F, Zorat F, Pozzato G, Faccini L, Campanacci L: Interferon versus steroids in patients with hepatitis C virus-associated glomerulonephritis. Digest Liver Dis 2000; 32:708-715.

20 Bruchfeld A, Lindahl K, Stahle L, Soderberg $\mathrm{M}$, Schvarcz R: Interferon and ribavirin treatment in patients with hepatitis C-associated renal disease and renal insufficiency. Nephrol Dial Transplant 2003;18:15731580.

21 Rossi P, Bertani T, Baio P, Caldara R, Luliri P, Tengattini F, Bellavita P, Mazzucco G, Misiani R: Hepatitis C virus-related cryoglobulinemic glomerulonephritis: long-term remission after antiviral therapy. Kidney Int 2003;63:2236-2241. 
22 Alric L, Plaisier E, Thébault S, Péron JM, Rostaing L, Pourrat J, Ronco P, Piette JC, Cacoub P: Influence of antiviral therapy in hepatitis $C$ virus-associated cryoglobulinemic MPGN. Am J Kidney Dis 2004;43:617623.

23 Saadoun D, Resche-Rigon M, Thibault V, Piette J, Cacoub P: Antiviral therapy for hepatitis C-associated mixed cryoglobulinemia vasculitis. Arthritis Rheum 2006;54:36963706.

-24 Garini G, Allegri L, Iannuzzella F, Vaglio A, Buzio C: HCV-related cryoglobulinemic glomerulonephritis: implications of antiviral and immunosuppressive terapies. Acta Biomed 2007;78:51-59.

25 Roccatello D, Fornasieri A, Giachino O, Rossi D, Beltrame A, Banfi G, Confalonieri R, Tarantino A, Pasquali S, Amoroso A, Savoldi S, Colombo V, Manno C, Ponzetto A, Moriconi L, Pani A, Rustichelli R, Barbiano di Belgiojoso G, Comotti C, Quarenghi M: Multicenter study on hepatitis $\mathrm{C}$ virus-related cryoglobulinemic glomerulonephritis. Am J Kidney Dis 2007;49:69-82.

26 Abbas G, Hussain S, Shafi T: Effect of antiviral therapy on hepatitis $\mathrm{C}$ virus related glomerulopathy. Saudi J Kidney Dis Transplant 2008;19:775-780.

-27 Saadoun D, Resche Rigon M, Sene D, Terrier B, Karras A, Perard L, Schoindre Y, Coppéré B, Blanc F, Musset L, Piette JC, Rosenzwajg M, Cacoub P: Rituximab plus Peg-interferon-alpha/ribavirin compared with Peg-interferon-alpha/ribavirin in hepatitis C-related mixed cryoglobulinemia. Blood 2010;116: 326-334.

28 Quartuccio L, Soardo G, Romano G, Zaja F, Scott C, De Marchi G, Fabris M, Ferraccioli G, De Vita S: Rituximab treatment for glomerulonephritis in HCV-associated mixed cryoglobulinemia: efficacy and safety in the absence of steroids. Rheumatology 2006;45: 842-846.
Petrarca A, Rigacci L, Monti M, Giannini C, Bernardi F, Caini P, Colagrande S, Bosi A, Laffi G, Zignego AL: Improvement in liver cirrhosis after treatment of HCV-related mixed cryoglobulinemia with rituximab. Dig Liver Dis 2007;39(suppl 1):S129-S133.

30 Roccatello D, Baldovino S, Rossi D, Giachino O, Mansouri M, Naretto C, Di Simone D, Francica S, Cavallo R, Alpa M, Napoli F, Sena L: Rituximab as a therapeutic tool in severe mixed cryoglobulinemia. Clin Rev Allergy Immunol 2008;34:111-117.

31 Saadoun D, Mesche-Rigon M, Sene D, Perard L, Karras A, Cacoub P: Rituximab combined with peg-interferon-ribavirin refractory hepatitis $C$ virus-associated cryoglobulinemia vasculitis. Ann Rheum Dis 2008;67: 1431-1436.

32 Ferri C, Cacoub P, Mazzaro C, Roccatello D, Scaini P, Sebastiani M, Tavoni A, Zignego AL, De Vita S: Treatment with rituximab in patients with mixed cryoglobulinemia syndrome: results of multicenter cohort study and review of the literature. Autoimmun Rev 2011;11:48-55.

33 De Vita S, Quartuccio L, Isola M, Mazzaro C, Scaini P, Lenzi M, Campanini M, Naclerio C, Tavoni A, Pietrogrande M, Ferri C, Mascia M, Masolini P, Zabotti A, Maset M, Roccatello D, Zignego A, Pioltelli P, Gabrieli A, Filippini D, Perrella O, Migliaresi S, Galli M, Bombardieri S, Monti G: A randomized controlled trial of rituximab for the treatment of severe cryoglobulinemic vasculitis. Arthritis Rheum 2012;64:843-853.

34 Ahmed M, Wong C: Should rituximab be the rescue therapy for refractory mixed cryoglobulinemia associated with hepatitis C? J Nephrol 2007;20:350-356.

- 35 Cacoub P, Delluc A, Saadoun D, Landau DA, Sene D: Anti-CD20 monoclonal antibody (rituximab) treatment for cryoglobulinemic vasculitis: where do we stand? Ann Rheum Dis 2008;67:283-287.

- 36 El-Serag H, Hampel H, Yeh C, Rabaneck L: Extra-hepatic manifestations of hepatitis $\mathrm{C}$ among United States male veterans. Hepatology 2002;36:1439-1445.
37 Perico N, Cattaneo D, Bibkov B, Remuzzi G: Hepatitis $\mathrm{C}$ infection and chronic renal diseases. Clin J Am Soc Nephrol 2009;4:207220

- 38 Sneller M, Hu Z, Langford C: A randomized controlled trial of rituximab following failure of antiviral therapy for hepatitis $C$ virusassociated cryoglobulinemic vasculitis. Arthritis Rheum 2012;64:835-842.

39 Basse G, Ribes D, Kamar N, Mehrenberger M, Sallusto F, Esposito L, Guitard J, Lavayssiere L, Oksman F, Durand D, Rostaing L: Rituximab therapy for mixed cryoglobulinemia in seven renal transplant patients. Transplant Proc 2006;38:2308-2310.

40 Fabrizi F, Martin P, Elli A, Montagnino G, Banfi G, Passerini P, Campise R, Tarantino A, Ponticelli C: Hepatitis $C$ virus infection and rituximab therapy after renal transplantation. Int J Artif Organs 2007;30:445-449.

41 McHutchison JG, Everson GT, Gordon SC, Jacobson I, Sulkowski M, Kauffman R, McNair L, Alam J, Muir A, PROVE1 Study Team: Telaprevir with peginterferon and ribavirin for chronic $\mathrm{HCV}$ genotype 1 infection. N Engl J Med 2009;360:1827-1838.

42 Hezode C, Forestier N, Dusheiko G, Ferenci $\mathrm{P}$, Pol S, Goeser T, Browicki J, Bourliere M, Gharakhanian S, Bengtsson L, McNair L, George S, Kieffer T, Kwong A, Kauffman R, Alam J, Pawlotsky J, Zeuzem S, PROVE2 Study Team: Telaprevir and peginterferon with or without ribavirin for chronic HCV infection. N Engl J Med 2009;360:18391850.

43 Ghany G, Nelson D, Strader D, Thomas D, Seeff L: An update on treatment of genotype 1 chronic hepatitis C virus infection: 2011 practice guidelines by the American Association for the Study of Liver Diseases. Hepatology 2011;54:1433-1434.

44 Saadoun D, Rosenzwajg M, Joly F, Six A, Carrat $F$, Thibault V, Sene D, Cacoub $P$, Klatzmann D: Regulatory T-cell responses to low-dose interleukin-2 in HCV-induced vasculitis. N Engl J Med 2011;365:2067-2077. 